\title{
Welcome to NorDiNa 3/12
}

It is with great pleasure we welcome you to the third issue of NorDiNa this year. The work with NorDiNa is running smoothly. The numbers of manuscripts submitted are increasing and we are constantly expanding the group of talented and effective reviewers. Also the circulation of NorDiNa is steadily increasing. We have now an edition of 700 copies and 370 subscribers - it increased three times with the free subscription. Approximately half of the subscribers are from Norway and a quarter each in Sweden and Denmark, respectively. Furthermore, many of the journals are distributed during teacher conferences and create a link between the research community and the practitioners. In this issue we present seven research articles, as always with a wide range of topics, a book review and two abstracts from recent dissertations.

Two of the articles focus on teachers and one on student teachers. Hanne Mehli and Berit Bungum present a case study of how science teachers benefit from participation at an in-service course on space technology at Andøya Rocket Range in Northern Norway. They have by in-depth interviews investigated how teachers' make use of their knowledge and experience in their classroom teaching. The article by Helena Sagar, Ann-Marie Pendrill and Anita Wallin identifies teachers' perceptions of requirements for including collaborations with the aim of providing authentic and entrepreneurial learning environments in their teaching practice. Irmeli Palmberg presents a study of 335 student teachers' knowledge of species and of factors that have influenced their interest in and capacity for identifying species. The study is based on a questionnaire and completing interviews. Pupils in grades 7 and 9 and adults were used as reference groups.

Annie-Maj Johansson and Per-Olof Wickman have made a comparative study of the Swedish national curricula during 50 years, focusing changes in what students should learn about scientific inquiry and about the nature of science. The results show that there have been many shifts during the period, both from learning based on an inductive method to a more deductive one, and from an emphasis on carrying out investigations to a more conceptual understanding of scientific investigations.

The title of the paper by Simen Sørby and Carl Angell is "Undergraduate students' challenges with computational modelling in physics". It is a qualitative study of the computational perspectives' impact on the students' work in a mechanics course, and their learning and meaning-making of its contents. They propose an instructive and dialogic text to help students who are new to computational modelling.

Two articles concern content and contexts of two different assessment instruments. Greta Tikkanen and Maija Aksela present an analysis of Finnish chemistry matriculation examination questions between 1996 and 2009 to investigate what kinds of cognitive skills and knowledge the examination questions require. The study has a qualitative approach and Bloom's revised Taxonomy of Cognitive 
Objectives was employed in the research. In the other article Eva Davidsson, Helene Sørensen and Peter Allerup explore how students' performances concerning scientific literacy are affected by the content and the context of the test from a gender perspective. The test investigated is ComputerBased Assessment in Science (CBAS). The results indicate different gender patterns depending on the items' content and context.

Helene Sørensen, Aarhus university in Denmark, presents a review of the second edition of Svein Sjøbergs book "Naturfag som almendannelse: en kritisk fagdidaktik". She has made a comparison between the first and second edition, and also adds a Danish perspective on the issues discussed in the book.

In this issue we also present two abstracts from recent dissertations in Finland, Maria Hofman, Åbo Akademi Vasa, and Antti Laherto, University of Helsinki.

We would like to inform you that from January 2013, Are Turmo will take over as NorDiNa editor for Sonja M. Mork. Sonja has enjoyed being one of the NorDiNa-editors for 2,5 years. During this period she has learned a lot about science education in the Nordic countries. However what she will remember most from the experience as editor is the way we are met by colleagues in the science education community when asking people to do review for NorDiNa. The positive responses and thorough work by the referees is really impressive. We wish Are Turmo good luck as new editor and take the opportunity to thank the following colleagues for the excellent work they are doing as reviewers for NorDiNa. Without them there would be no journal.

\begin{tabular}{|l|l|l|}
\hline Åsa af Geijerstam & Øystein Guttersrud & Ola Magntorn \\
\hline Jonas Almqvist & Glenn Hultman & Gunilla Näsström \\
\hline Maria Andree & Björn Håland & Carol Nordberg \\
\hline Diana Arya & Malin Ideland & Clas Olander \\
\hline Sylvia Benckert & Åke Ingerman & Irmeli Palmberg \\
\hline Sascha Bernholt & Anders Isnes & Sverre Pettersen \\
\hline Madelen Bodin & Gunnar Jonsson & Michael Reiss \\
\hline Berit Bungum & Kalle Juuti & Eva Silfver \\
\hline Anna Danielsson & Pål Kirkeby Hansen & Astrid Sinnes \\
\hline Margareta Ekborg & Marit Kjærnsli & Svein Sjøberg \\
\hline Margareta Enghag & Tom Klepaker & Jarle Sjøvoll \\
\hline Marianne Foss Mortensen & Christina Kärrqvist & Bodil Sundberg \\
\hline Merethe Frøyland & Britt Lindahl & Odd Valdermo \\
\hline Marcus Grace & Christine Lindstrøm & Anna Vikström \\
\hline Barbro Gustafsson & Mattias Lundin & \\
\hline
\end{tabular}

Enjoy your read!

Christina Ottander Sonja M. Mork S S S S S S $\quad$ Soin Serg 